\title{
LEGISLATIVE RESTRICTIONS OF THE ISLAMIC CONSULTATIVE ASSEMBLY DUE TO THE LEGISLATIVE JURISDICTION OF OTHER AUTHORITIES IN THE PROCEDURE OF THE GUARDIAN COUNCIL
}

\author{
Javad Roshanzadeh $^{1^{*}}$, Seyed Ahmad Habibnejad ${ }^{2}$
}

${ }^{1}$ Ph.D. Student, Department of General Law, Qom Branch, Islamic Azad University, Qom, Iran, ${ }^{2}$ Assistant Professor, and Faculty Member, Department of General Law, University of Tehran, Farabi Pardis, Qom, Iran.

Email: "groshanzadeh@gmail.com

Article History: Received on $12^{\text {th }}$ October 2019, Revised on $29^{\text {th }}$ November 2019, Published on $19^{\text {th }}$ December 2019

\begin{abstract}
Purposes: In the Constitution of the Islamic Republic of Iran, in accordance with Article 71 , legislation is the responsibility of the Islamic Consultative Assembly and has general jurisdiction which does not mean that the Islamic Consultative Assembly has no restrictions on legislation, but has limitations in terms of the various Constitutional principles including, the exclusive and particular jurisdiction of other authorities to legislate the law. The Islamic Consultative Assembly cannot legislate in the jurisdiction of these institutions. In the Constitution, a series of authorities have got the right to legislate.
\end{abstract}

Methodology: Using an analytical descriptive method, the present article seeks to examine the question of what are the legislative constraints of the Islamic Republic Consultative Assembly in the Guardian Council's procedure.

Results: In the procedure of the Guardian Council, other authorities, such as the Assembly of Experts of the Leadership, the Expediency Discernment Council of the system, the Supreme National Security Council, the Supreme Council of the Cultural Revolution, etc. have found the right to legislate. In other words, this general jurisdiction has been assigned in a way.

Implications/Applications: The application of this study is to introduce the laws of the Islamic Republic of Iran. The exercise of this jurisdiction by the Islamic Consultative Assembly has a framework that cannot be explained except by referring to the Constitutional principles

Novelty/Originality: In the Constitution of the Islamic Republic of Iran, due to the nature and type of government and the particular aspirations pursued, other legislative authorities include the Assembly of Experts, the Expediency Council, the Supreme National Security Council. It is accepted that by referring to the views of the Guardian Council as the Constitutional body, they have protected them in cases where the jurisdiction of these authorities has been invaded.

Keywords: Legislative Constraints, Jurisdiction, Legislative Authority, Guardian Council.

\section{INTRODUCTION}

Legislation or codification is one of the most important competencies of the government and the inherent jurisdiction of the legislature. In accordance with Article 71 of the Constitution, the Islamic Consultative Assembly has the power to legislate in accordance with the mentioned Article and, by virtue of the above-mentioned provision, can legislate in all matters. And legislation is the mandate of the Islamic Consultative Assembly. The legislation is one of the most important tasks of the deputies and cannot delegate it to a person or a group. During the Constitutional Revolution, the Council repeatedly granted such an option to others, and the Constitutional Court reacted itself by the ratification of Article 85. Nevertheless, they have foreseen exceptional cases. Lawyers in this regard have expressed different views in regard to the principle of separation of powers and their degree of interest. After the incidents of World War II, there are some tendencies toward the transfer of legislative power from Assembly to government. In the UK, the cabinet, which initially had the right to legislate in the framework of legal texts, gradually decided on purely legal contexts. In the French Constitution of 1946, the principle of non-transferring was as follows: "The National Assembly passes the law and this right cannot be delegated to anyone," but the Constitution of the fifth Republic of 1958 accepted the principle of constitutional authority delegation. (Hosseini, 91, p. 91) In the system of the Islamic Republic of Iran, according to the type of system and the various objectives pursued, numerous institutions of legislation can be observed. i.e., In addition to the jurisdiction of the Islamic Consultative Assembly in legislating, due to the nature of the revolution and the Islamic system, other institutions are also authorized to approve the binding rules as important as the law of ordinary or superior to it or the legislation on the particular subjects. Which has been recognized as "legislative authority" in the system of the Islamic Republic of Iran (Gholam Hossein \& Nouraei, 2015)? Now, with a descriptive and analytical method, this article seeks to answer the main question, what are the legal restrictions of the Islamic Republic Consultative Assembly, resulting from the jurisdiction of the legislature for other authorities, which authorities would be included? What are the Guardian Council's procedure and views on these authorities?

\section{GENERALITIES AND FUNDAMENTALS}

First, in order to clarify the discussion, it is necessary to give a definition of the law and the legislature's authority. The law has its own legal definition and concept. Lawyers have divided the law into two general categories. The law in the 
general meaning is all the rules imposed by one of the qualified organizations of the government; Whether it is the legislative body or head of government or one of the members of the executive branch. But the law, in the specific sense, as it is contemplated in fundamental rights, is said to be in accordance with the rules established by the Legislative Power (Katouzian, 2006).

\section{The Principles and Fundamentals of Legislative Limitation of the Assembly}

\section{Principle of Separation of Powers}

The separation of powers is the principle in public law, according to which the government is divided into separate powers to prevent oppression. This principle originally appeared in the West and placed a political influence on political systems, then by the acquaintance of statesmen and elites, it was stated in countries that led to theoretical debates and actions to change the structure of the governments (Alem, 2003). When the legislative and executive powers are at the hands of one person or in the hands of a single group of governors, freedom will not be possible, because then it will be feared lest the Assembly will legislate oppressively and implement those laws in an oppressive manner. If the judiciary is not separated from the legislature, there will be no freedom, and if combined, the life and freedom of the citizens will be subjected to arbitrary domination because in that case, the judge will be the same legislator. Since in a free country, people who are freelancers should be rulers of their lives, so the legislative authority should be in the hands of the whole people, but because this is unfeasible in a large country, and in the small countries it also faces many difficulties, so it is better for people to do, what they cannot do, through their representatives (Lufan Boomer,2006).

According to Article 57 of the Constitution, the ruling powers in the Islamic Republic of Iran are the legislative, executive and judicial branches under the supervision of the absolute authority of the Leader of the nation (the Imams of the Ummah) according to the future principles, this law would be executed. This power is independent of each other. According to Article 58 of the Constitution, the acts of the legislature are through the Islamic Consultative Assembly. Also, in accordance with Article 71 of the Constitution, the Islamic Consultative Assembly may legislate the law in public matters within the limits established by the Constitution and in accordance with Article 85 of the Constitution, cannot delegate legislative authority to a person or an individual.

One of the separations of powers aspects, is the separation of functions and the special function of each power, that is, the jurisdiction $\mathrm{s}$ are distributed between each of the three powers and divided according to the nature of their functions, that is, the Legislative Power has the power to legislate, and the Jurisdiction Power has been granted the executive and to the judiciary, the Jurisdiction of the Judge and the arbitrator, so each of the forces are primarily in the field of its own specialized jurisdiction and their other jurisdictions are subordinate and exceptional (Fallahzadeh \& et al.,2018).

Regarding the legislation, from the totality of the principles mentioned in the Constitution, it can be understood that the legislative process is a special legislative function and that every legislative matter is devoted to the legislature, and that the other powers should not enter into the main inherent field of the legislature.

\section{Ruling of Law}

The rule of law is one of the fundamental values in which public affairs is governed by general, transparent, and forward-looking rules. The claim is that this way, in the public governing, it is one of the first steps necessary to achieve justice, as the heart and center of political values. The lack of ruling of law (general rule) in the sense of communal life means the existence of sovereignty of a vote and a personal demand (a particular and partial rule) that has been named in the political history as the tyranny. In fact, over the past three centuries, the basic modern laws and the political systems have developed to confront despotism, formed as a supreme form of injustice (Rasekh, 2011, p. 22). Therefore, the ruling of law is considered to be the main substantive and fundamental value in shaping the structure of political power. "The mere existence of a Constitution" in a country implies a nation's demand for the rule of the general, transparent law, and observing the events and future actions on public affairs. In this way, a nation emerges from the "ignorant of the law and the legal system" (a world governed by personal, trivial and exclusive rules) and goes into the realm of "rights" (the sovereignty of general rules).

However, the existence of general rules in the necessary public domain does not mean the absence of monopoly, selfishness, discrimination, and other forms of oppression. The concentration of political power in the hands of a person or group with regard to the wide range of powers and jurisdictions of the government - can lead to corruption and the rule of general but oppressive rules, and this can be imagined in various types of government in varying degrees. Therefore, it is necessary not to have all the power of government available to a person or group. In addition, the expansion of the state over the last several centuries and the experience of extensive government activities have shown that these activities or functions can be divided into several general and relatively independent groups. On this basis, political power has been divided into different branches and, in so-called technical terms, a system of separation of powers has been created. The separation of powers reduces to some extent the probability of corruption and oppression and also requires the division of labor in the government. It is clear that separation of powers is the second element that constitutes a system of fundamental rights, which, with the completion of the ruling of law, contributes in part to the achievement of justice (Rasekh, 2011, pp. 22-24). 
Under the provisions of the Constitution, state power and government functions are distributed among three powers and one institution, which is the legislature, the judiciary, the executive branch, and the leadership institution. Each of these forces can have a specific structure and it is not necessary to have a specific structure in all systems of fundamental rights. Accordingly, it is quite possible that the legislature is a two-state institution in one country and in another one is an individual state, as in the real world, there are such systems of legislation (Rasekh, 2011, pp. 43-44).

\section{The principle of non-delegation of Legislative Power}

In accordance with Article 85 of the Constitution, the Islamic Consultative Assembly cannot delegate legislative authority to a person or committee. Of course, this principle has also its exceptions that include the above-mentioned principle, the following principle (statute) and the provisions of Article 138 concerning the enactment of Regulations and Decree. Therefore, in cases where there is doubt about the delegation of the legislature, it should refer to the principle and base it on the principle of non-delegation of legislative power, unless there is an explicit reference text. Concerning the issue of merging or dissolving the organization of management and planning of the country, definitely not the basic and nor ordinary legislative, has the qualified authority to determine the status of a legal entity or to modify and change it to an authority, institution and someone else, and there is no such script (Fallahzadeh et al. 2018, p. 274).

\section{The superiority of the Constitution Principle}

The special significance of the Constitution among other laws is due to its relation to the general legal-political structure of each country. The Constitution al right respect means the guarantee of the stability and continuity of the frameworks of the government-country and the political regime in each society. Therefore, in countries governed by Constitutional law, the legal system and the legitimacy of all institutions and the validity of their acts are based on Constitutional law and these principles are fundamental. The Constitutional law identifies the jurisdictions of institutions and powers and, therefore, is superior to all powers and institutions. (Hossein Ali, 2016, p. 72)

\section{The Hierarchy of Rules Principles}

One of the basic principles of law and legislation is the adherence of the lower-class rules to the law of the supreme class. This principle, which is known as the hierarchy of laws, has regulated the laws of the countries. The rules that govern the ruling of law and the jurisdiction powers of the country and the rights and freedoms of individuals are fundamentally Constitutional and superior to other rules of law. The recognition of ordinary laws is not always possible with this criterion, since some of the sub-rules sometimes come under the fundamental laws, and it is likely that one of the rules of the state's principle is considered as ordinary law. With these explanations, the most reliable sign of the Constitutional law is its formal legislation procedure. The Constitutional law of countries is set up in the constituent Assembly, composed of elders and elites of the society, and approbated in a referendum from the public. It is also not easy to change and revise. The rules of the hierarchy of rules are important. In today's world, less country is that its legal system has not established hierarchies among the laws. When it comes to the hierarchy of rules, we must accept the fact that the country indispensable laws that are in force are not equal in value and importance, and there are laws and regulations that are superior to other laws and regulations. Therefore, less important rules and regulations should not be in conflict with superior rules (Hossein Ali, 2016; Kasteyeva, 2018).

\section{Qualified Legislative Authorities}

According to what is witnessed in the Islamic Republic of Iran, some authorities have a higher qualified legislative status, as specific jurisdiction, in the Islamic Consultative Assembly, such as the Assembly of Experts, the Expediency Council, the Supreme National Security Council, the Supreme Council of the Islamic Cultural Revolution and High Cyberspace Council. These authorities, who have more limited legislation in scope and largely are devoted to specific issues, also their ratification is subject to a higher order than ordinary law. In addition to the Islamic Republic of Iran, which has numerous law enforcement agencies, it may be possible, in other systems, to see some kind of legislative authority, such as the federal countries that each member federal state of the country has its own Assemblies and is entitled to the law in the jurisdiction conferred by the federal Constitutional law, and in the event of a disagreement between the assemblies and the central assemblies, a Supreme Federal Court will decide. Also, countries that have bicameral assemblies, if they have faced parallel issues on some topics, such as the French budget law. Another case that is visible in the circle of the various law enforcement agencies in other legal systems is related to the law delegation; but an authority which, in addition to the legislature, is competent in the Assembly and is common to the legal system of Iran and other countries, is referendum and direct referral to public vote. The status of a referendum in the enactment of the law, depending on the issue of the referendum, is either level or superior to the Assembly. In Italy, another kind of referendum, which is actually a veto right is used in the sense that five hundred thousand voters from citizens, or five district councils, can request the lifting of Parliamentary law. As a result, this request must be submitted to the referendum. However, the cancellation of the Parliamentary decree is subject to the approval of the majority of eligible voters for voting in the referendum, and the majority of votes received will be in accordance with the cancellation of the mentioned law credit (Ghazi, 2018, p. 428). Therefore, in the Constitutional law of countries, there are other authorities other than the Assembly for the adoption of a specific type of law and sometimes considered as limits to refer to public or referendum, which, of course, cannot be legislated by the Assembly in that domain of law. Article 71 of the Constitution, which states that "the Islamic Consultative Assembly can, in public matters ..., legislate", indicates that the 
exclusive jurisdiction of the Assembly in the law enforcement is a general jurisdiction and involves the general issues, while under the article 8 of the Constitution, the issue is out of the jurisdiction of the Assembly. Exceptional issues that sources other than the Islamic Consultative Assembly have found the right to legislate are as follows:

\section{Enactment of Law through the Referendum}

One way of limiting the legislature is to use the referendum. If in a country executive power has the authority, instead of the Assembly, it will use the referendum to enact the creeds i.e., the legislature will be weakened, and if it is impossible to go directly to the nation, the Assembly will have exclusive power. Therefore, in the basic rights of countries, the issue of referendum or unanimous national ratification is not introduced or is prohibited in certain cases, limited in certain cases or prescribed conditionally. And sometimes it can be used extensively. Indeed, in the rule of democracy, it is the supreme power and sovereignty exclusively for the people, and determining in what ways should be their relations with the ruling body, is with them, and the most obvious way of expressing the will of the public is to refer to public opinion, and if it was possible to solve each community matter with the national ratification, real democracy was realized, although it has been true in rare cases. Like the Greek city government, all regulations should be passed by the people. And it is still acted in some cases subject to conditions.

The subject of a referendum may be related to a treaty, or a change in the country's education system, or, for example, the addition of taxes, although the adoption of such matters is essentially within the Constitutional framework and the Assembly itself, however, in order to attract more people's support or because of doubt in the government it is put to a referendum, it is sometimes resolved through a referendum and national approval by the legislature and its decisions or opposed. And the goal is that people directly express their opposition to the law passed by the legislature, as in Italy, at the request of five hundred thousand people who have the right to vote or on the proposal of five district councils, the version of the law passed by the Assembly is referenced to the general vote. Such a law will be effective only if the absolute majority of the participants in the referendum vote are in their opposition. The right to dispose of the laws through a referendum and in the aforementioned manner would include the treaties that are not passed by the Assembly (Madani, 1995, p. 158). In the Constitutional Law, the prospect of direct recourse to public opinion was not introduced. When in 1953 the government decided to dissolve the Assembly through a referendum, such a measure was considered unconstitutional. After the Islamic Revolution, the first step in the referendum was to determine the type of government. In April 1979, people were asked whether they wanted a government of the Islamic Republic or a Constitutional monarchy, and only after that, the election that the Assembly of Experts was held and they received the mission of the Constitutional mandate of the Islamic Republic. The final ratification of the Constitutional law in 58 and its reforms in 69, through direct referral to the general vote, also the Constitution accepted the referendum as the legislative authority, in addition to the sixth principle that the country's administration is based on popular opinion and referred to a referendum. Article 59 of the Constitutional law states that in matters of very important, economic, political, social and cultural issues, legislative acts may be conducted through referendum and direct referrals to people's votes (Madani, 1995, pp. 158-159).

\section{The Law Legislation by the Jurisprudents of the first Guardian Council}

According to Article 108 of the Constitution: "The law concerning the number and conditions of the experts, the quality of their choice and the internal rules of their sessions for the first period shall be prepared by the jurists of the first council of guardians and be approved by a majority of their votes and approved by the final decision of the leader of the revolution."

\section{Approval of Rules by Leading Experts}

The Assembly of Experts has the authority to amend or revise "the law on the number and conditions of experts and the quality of their choice." Also, the approval of other rules related to the duties of experts is in their jurisdiction. According to article 108, "... from now on, any change and revision of this law and the adoption of other regulations related to the duties of experts are in their own jurisdiction." The main task of the Assembly of Experts is to lead the election and supervision on the Supreme Leader. In this regard, the Constitution also provides the authority for the Assembly of Experts. Article 108 of the Constitution states that the law concerning the number and conditions of the experts, the quality of their choice and the internal rules of their sessions for the first period should be prepared by the jurists of the first period Guardian Council and approved by a majority of their votes and passed finally by Leader of the Revolution. Since then, any change and revision of this law and the adoption of other regulations related to the duties of experts in their jurisdiction is in accordance with this principle of the Constitutional principles that some lawyers believe in the legislative jurisdiction of the Assembly of Experts of the Leadership within the scope of Article 108 of the Constitution (Habib Nejad, 1999, p. 168).

Based on the above principle, the Assembly of Experts of Leadership, although not competent to legislate, is exceptionally authorized to legislate on the internal administrative rule and the law of the Assembly of Experts elections. In contrast, some believe that the law has a specific legal definition of its own experts. Therefore, the rules and regulations ratified by any other institution are not covered by the law specifically in meaning. In the discussion of the Assembly of Experts, the legislature should not be introduced as the duties of that Assembly, and the authors' action in this naming is also only a matter of negligence. As a result, the Assembly of Experts on the approval of the provisions of 
Article 108, including the Code of Conduct of the Assembly of Experts and the Law on the election of the Assembly of Experts, is in the legislature power of the Islamic Consultative Assembly and has exclusive jurisdiction over the two issues mentioned above. Therefore, the plurality of legislative bodies occurs. However, this multiplicity will not be challenging until this legislation is in a clash with the legislative task of the legislature (Habib Nejad, 1999, p. 168).

\section{Approval of Regulations by the Expediency Council}

Notwithstanding the duties of the Assembly, according to the final paragraph of Article 112: "The provisions of the Assembly shall be made and prepared by the members of the Assembly, and approved by the Supreme Leader". The Expediency Council is the institutional system that was established before the revision of the Constitution in 1989, based on principles 5 and 57 of the Constitution and by the Jurisprudence order of "Velayat" (supreme jurisprudent). Imam Khomeini (RA), through a decree on 1988/2/6, established this council. Therefore, the legal legitimacy of this institution before the revision of the Constitution was based on the ruling of the supreme jurisprudent, but after revising the Constitution, Article 112 of the Constitution was assigned to the Council and its functions. Article 112 of the Constitution of 1989 states: "The Expediency Council for the recognition of system issues in cases where the ratification of the Islamic Consultative Assembly is considered by the Council of Guardians to be contrary to the provisions of the Shari'a or the Constitution, and the Assembly, or not taking into account the expediency of the Council of Guardians view, and the council and advice on matters of which the leadership has referred to them and other duties mentioned in this law, are formed on the order of the leader. The fixed and variable members of this assembly will be appointed by the Supreme Leader. The rules of the Assembly will be drafted and approved by the members themselves, and will be approved by the Supreme Leader." (Nouraei, 2013,p. 7)

\section{Ratification of Regulations by the Supreme National Security Council}

The Supreme National Security Council, in the framework of the powers conferred upon it by the Constitution, ratifies the regulations that are applicable after the approval of the Supreme Leader. The Supreme National Security Council is constituted in accordance with Article 176 of the Constitution. According to this principle, the Supreme National Security Council is headed by the President in order to provide national interests and protect the Islamic Revolution and territorial integrity and national sovereignty with the following duties:

"1) defining the country's defense and security policies within the overall policy defined by the Supreme Leader; 2) coordinating political, informational, social, cultural and economic activities in relation to general defense-security measures; 3) utilizing the material and spiritual resources of the country to face internal and external threats." (Nouraei, 2013, p. 8)

It seems that from the above tasks it can be understood that the main legislator has recognized the legislative powers in defining macro-defense and security policies and coordinating all activities in relation to general defense and security and utilizing the material and spiritual resources of the country for the mentioned goals defined by the Supreme Leader for the Supreme National Security Council in light of the overall policy defined by the Supreme Leader. Although some of the council's duties are defined in terms of large-scale policies and differentiated between policy-making and legislature, given the use of the terms in principle 176, the jurisdiction of this council is not limited to macro policies. The history of the Supreme National Security Council has also shown that the jurisdiction of this council is not merely a matter of macro policy, but also the adoption of executive decisions and the case in which the security and defense aspects of the Islamic Republic of Iran require them to be necessary; And this is not in conflict with the terms in the three paragraphs of Article 176 of the Constitution regarding the duties of the Supreme National Security Council. The duties and powers of the Supreme National Security Council on matters covered by Article 176 of the Constitution indicate the superiority of the council's approvals to other ordinary laws since the mandate of this council should be approved by the Supreme Leader; Therefore, the council acts independently of the three powers in making its decision, while in policy of coordinating the country's affairs with security defenses, this power, on the contrary, is subordinated to and subject to the influence of the council. Thus, after the approval of the Supreme Leader, the council's resolutions affect the decisions and approvals of the three forces, in particular, the legislature and the executive, and maybe the law or regulations in this regard are, in whole or in part, revoked or violated (Hashemi, 1998, p. 650).

\section{Result and discussion}

The authorized revision body of the Constitution is the Revision Council, which is foreseen in Chapter 14 of the Constitution. According to Article 177 of the Constitution: "The decisions of the Revision Council, after the approval and signing of the Supreme Leader, must reach the general vote by referring to the general vote to the absolute majority of the participants in the referendum."

\section{Ratification of Regulations by Local Islamic Councils}

In the current legal system, at least 4 types of councils are visible:

- Superior and supreme courts such as the Council of Supervisors or the Supreme Council of Cyberspace. 
- Superior councils within the executive branch or other bodies and institutions such as the Economic Council or the Supreme Council of Education or the Supreme Administrative Council.

- Islamic City Councils and Village. - Factory and School Schools and Wards councils.

First-category councils decide second-category councils have an advisory role, local councils of the city and village have both supervisory role and advisory role as well as in some cases, and the last category is neglected in the legal system. (Principle 7).

According to Article 7: “... councils, the Islamic Consultative Assembly, the Provincial Council, the state, the city, the region, the district, the village, etc., are the skeleton of the decision making...", and in accordance with Article 12, the mentioned councils shall regulate the local regulations in each region where the followers of each of the five lawful religions of Hanafi, Maliki, Hanbali, Shafei, Zaidi have a majority, according to that religion, will preserve the rights of followers of other religions and within the limits of the authority of the councils.

Although, according to Article 103, "governors, proconsul, Prefect, and other government officials appointed by the government are required to comply with their decisions within the bounds of the councils", but according to article 105 "The decisions of the councils should not be opposed to the standards of Islam and Rules of the country ". Therefore, according to the above rules, Islamic councils establish local regulations, and the Islamic Consultative Assembly approves national regulations. In view of attending to the role of the people in the religious democratic system of the Islamic Republic, according to Principles 100-102, the Supreme Council of the provinces has the right to draw up plans for the prompt promotion of social, economic, developmental, health, cultural, educational and other welfare programs of the country, directly or through the government, by submitting to the Islamic Consultative Assembly, (Hosseini, 91).

\section{The Legislation by the Executive Branch or the Parliamentary Commissions}

The representative of the people does not have a lawyer as "deputation", that is, the possibility of assigning the position assigned by the people to the other, and therefore cannot delegate this power to the person or group, and even the domestic commissions do not have the right to legislate. On the other hand, the legislature should not be entrusted to non-Assembly, because it is contrary to the principle of separation of power and against the Expediency, However, because negotiations between deputies in the Islamic Consultative Assembly and the observance of ceremonies required for the ruling of law often delay the adoption of laws. For this reason, the Constitution, in cases where it is felt necessary by a prompt legal situation, not only permits the law to be conferred on non-parliamentary chambers; for example, the government or government commissions, but the right to delegate legislative power to the Islamic Consultative Assembly and the commissions or the government. The assignment of legislative authority is in the following ways:

\section{The Delegation of Legislative Power to the Parliamentary Commissions}

According to Article 85: "The representation of a person is given to a person and cannot be delegated to another. The Assembly cannot delegate legislative power to a person or group, but in cases of necessity, it may delegate the power to enforce certain laws in accordance with article 72 to its internal commissions. In this case, these rules will be put into practice in a Parliamentary term, and their final approval will be with Assembly. "Recognizing this as subsequently mentioned in principle 96 is with the Guardian Council. In addition, the government's approvals should not violate the general laws and regulations of the country, and in order to verify and declare their non-compliance with the abovementioned laws, they must be announced to the speaker of the Assembly for implementation.

\section{The Power of Legislation of the Government, Based on the Permission of the Legislature}

The legislature in some cases, for certain reasons, such as preventing the wasting of the legislature time, the technicality and specialty of certain laws, and the need for the immediate adoption of certain regulations, permits the drafting of the law known as the "Code" in the administrative law to the executive branch. These Regulations are the implementing regulations, ratified in order to enforce the law, or in order to determine the details and options of the law, which is referred to as a substantive or independent Code.

\section{The Authority of the State Legislature, Arising from the Constitutionality of the Government}

In accordance with Article 138: "In addition to cases where the Cabinet of Ministers or the Minister becomes responsible for the codes of administrative rule, the Cabinet of Ministers shall have the right to establish law and regulations for the performance of administrative duties and the enforcement of laws and regulations of administrative agencies. Each of the ministers also has the right to establish regulations and issue a letter of intent in the scope of their duties and approvals of the Cabinet of Ministers, but the regulations' provisions should not be opposed to the text and spirit of the law." (Hosseini, 91).

\section{Leadership Orders}

According to the constitutional principle of the fifty-seventh, the three powers under the rule of the absolute authority of the Imam of the Ummah (supreme jurisprudence) are independent of each other. It is clear that the position of leadership in the Islamic Republic is above the other powers and overlooks them. According to paragraph 1 of Article 100, 
determining the general policies of the Islamic Republic of Iran, consulting the Expediency Council is one of the duties and powers of the leadership. Hence, it should be said that his leadership and his orders, which are the effects of these rulings, are higher than the Constitutional laws of the Islamic Republic in terms of the order in the basic rights of the Islamic Republic, and entry into this area is one of the legislative constraints of the Assembly. In fact, the general policies of the system are upstream documents that determine the general lines of movement of the country in different areas, and it is clear that the laws of the Assembly should move along these policies and not be contrary to these documents. In other words, the orders of the leadership are one of the issues that have led to a large number of legislative authorities in the Islamic Republic of Iran's Constitutional system. In accordance with Principles 57 and 110 of the Constitution, the Supreme Leader has the authority and duties to act by virtue of Article 57 of the Constitution independently and in accordance with Article 110 of the Constitution through the Expediency Council. So far, the leadership has exercised his authority in different levels of leadership in the Islamic Republic of Iran. According to Article 57 of the Constitution, the Supreme Leader not only has established institutions that have the authority to make decrees in the law and beyond the law, but also in some cases, by the ratification of the government prevents the adoption of an Islamic-dissuasive bill in the Islamic Consultative Assembly or canceled it. And in some cases, it also restricted the legislative power of the Islamic Consultative Assembly in areas that are relevant to the jurisdiction of the Supreme Council of the Cultural Revolution. Therefore, the policy of the Supreme Council of the Cultural Revolution and the policy of the Expediency Council is the one that limits the Parliamentary legislature (Jafar Gholikhani, 2015, p. 373).

\section{The Supreme Council of the Cultural Revolution}

How does the Council deal with the legislature of the country, whether it has obtained permission from the Constitution or through a government decree? It should be answered that in none of the Constitutional principles of the Supreme Council, the name of the Cultural Revolution has not been mentioned. This council is essentially an evolved institution of the Cultural Revolutionary Staff formed after the Constitution of the Islamic Republic of Iran and has not been paid any attention in its 68th revision. It would be better, as the Expediency Council, to address this matter, and consolidate its position in the Constitution. As you can see, this legal vacancy in the fundamental rights is of the ordinary type. By studying the history of the formation of the Supreme Council of the Cultural Revolution, it is noticeable that the President of the time has researched the validity of the decisions of the Supreme Council of the Cultural Revolution. The Supreme Leader replied on 1985/2/25 as follows: "The rules and regulations that the High Council of Cultural Revolution arranged should be attended "It is noticeable that this council has obtained the authorization for the establishment and validity of its approvals from the ruling of the supreme leader of the time. After the victory of the Islamic Revolution and the necessity of reforming the cultural space of the country, the need for Islamicization of the universities, which had a significant impact on the reform of the culture of society and became a major concern for the elite of the community and the people of the nation, was ordered by Imam Khomeini On 1980/6/13, the "Cultural Revolutionary headquarters" was formed and assigned special and specific duties on the Islamicization of universities. Later, in order to improve the performance of the headquarters of the Cultural Revolution and strengthen the field of achieving its mission, changes were made in headquarters, and Imam Khomeini (RA), ordered replacing the headquarters of the Cultural Revolution, the "Supreme Council of Cultural Revolution" in December 1984, and the major and broader jurisdiction, was to remove society from Western culture and replace the Islamic culture and make the Islamic Revolution more fertile in the country. Therefore, the Supreme Council has since passed important provisions that have been challenged and contested in many cases under the authority of the legislative institution, being the main regulatory body. Regarding the decisions of the Supreme Council of the Cultural Revolution, we can say that this council is an institution that has not been mentioned in the Constitution and has been established on the basis of the order of Leader of the time, and its approvals have been made binding. (Introduction to the Supreme Council of the Cultural Revolution, p. 5).

\section{High Council of Cyberspace}

The council was established on 2012/3/7 by a decree by the Supreme Leader, in which there are the head of forces and some other members of the system. The responsibility placed on this institution was due to the legal vacancy felt in the issue of cyberspace in the community and its influence on the personal and social life of individuals. The formation of this council for the serious matters, entrusted is to require the decisions and approvals of its members to be in a position to be followed by all the relevant organizations and to have a proper obligation. Therefore, the Supreme Leader has approved the ratification of this newly instituted body, and the statement issued by the Supreme Council of Cyberspace on this occasion is constituted by the presidency of the President, and it is necessary for all its approvals to be attended the same way for all institutions. It is necessary to follow the decisions of this institution, which "given the obligatory law, to be the command of leadership," and they are required to be observed by them (Nouraie, 2013, p. 19).

\section{GUARDIAN COUNCIL'S VIEWS ON THE LEGISLATIVE AUTHORITIES IN THE LEGAL SYSTEM OF THE ISLAMIC REPUBLIC OF IRAN}

As mentioned in the Constitution of the Islamic Republic of Iran, some law enforcement agencies are in a particular jurisdiction, those are authorities whose scope of authority is more limited and which are mainly devoted to a particular 
subject. In this section, we will review the authorities in the Guardian Council, although, for some of these authorities, the Guardian Council may lack opinions, both normal and interpretative.

\section{Assembly of Experts Leadership}

The Islamic Consultative Assembly has no jurisdiction over the Assembly of Experts, and the Guardian Council has disputed them in cases where the Islamic Consultative Assembly violated this right of Assembly of Experts. For example, the Guardian Council, in the Opinion No. 82/30/2944 of 2003/5/7 concerning the bill on the amendment of the provisions of Chapter II of the Law on the Determination of the Limits, Duties, and Responsibilities of the Iranian Presidential ratification, dated 1986/11/13 of the Islamic Consultative Assembly entitled "The President's Responsibility for the Implementation of the Constitutional law" approved by the Islamic Consultative Assembly on 2003/4/8, the inclusion of government agencies regarding the Leaders of the Experts and the Guardian Council, the Expediency Council and the Consultative Assembly and the Judiciary, and any other authority and Constitutionally empowered authority or mandated by them, the detection, perception, type and quality of the exercise of this authorization and liability are known to be in violation of Article 108. The Guardian Council, in the Opinion of the numbering $94 / 102 / 4506$ of 2015/11/25 regarding the amendment to the draft law on the election of the Islamic Consultative Assembly, approved by the Islamic Consultative Assembly of 2015/11/1, since the general decree of the Assembly on other elections, or the generalization of the ruling of the Assembly, should not be in such a way to include the election of the Assembly of Experts or the rules of the Assembly of Experts, it is also rejected, because the ratification of the law concerning the number and conditions of the experts and the quality of their selection after the first period is in the jurisdiction of the experts themselves and the Assembly should not interfere. Equally, generality in Parliamentary decrees should not include institutions in which the Assembly does not monitor their affairs, such as the Assembly of Experts, etc., which are subject to the law in accordance with the Constitution and other laws. This issue has been highlighted in the Opinion No. 86/30/25050 dated 2008/2/7. As well as in Opinion No. 88/30/37758 of 2010/3/17 of the Guardian Council regarding the drafting and enacting of the regulations of the country approved by the Assembly of the Islamic Republic of Iran on 2010/1/2. Article 2 of this plan, insofar as it includes the institutions that the Assembly does not monitor their affairs; Such as the Assembly of Experts, the Supreme Council of the Cultural Revolution, the Expediency Council, the Guardian Council, the Supreme Court of the country, the Administrative Justice Court, as well as other institutions that are in accordance with the Constitution and other laws, they have the right to ratification of law, which are contrary to this principle and other principles of the Constitution. From all of these views, it is argued that the Islamic Consultative Assembly does not have the power to legislate on the issues related to the Assembly of Experts and, in this regard, has a legislative limit.

\section{Leadership}

The Islamic Consultative Assembly cannot legislate on leadership. Often, the legislative restrictions on leadership are on the duties and authority of the leadership and the institutions and areas under which they are governed by him. We mention the most important things below.

\section{General Policy of the System}

General policies are a set of macro-system orientations and strategies for achieving the goals and objectives of the Constitution in a given time frame (Ansari, 2006, p. 185). In other words, macro policies, the same as defining the goals of the general policy which is outside the legislative domain and is almost the same as the base of law and the general spirit of the law. In jurisprudence, there are also general rules such as harmless discipline, the negation of hardship, and so on, on the basis of which many judicial decrees have been issued ... the position of the general policies of the state is more of mediocracy. The general framework (values and objectives) is set by the Constitution, and minor issues are discussed by the Assembly. General policies should, in accordance with the requirements of time, clarify the legislative framework and principles that should be emphasized in specific circumstances, (Aresta, 2001, p. 377), about the legal status of the general policy of the system in the hierarchy of norms some lawyers believe that the general policies of the system are considered to be religious judgments and rules, and they are considered to be state rulings and that the Guardian Council declines any laws and regulations adopted contrary to the policies in conflict with the Shari'a. (Aresta, 2001, p. 391); the Guardian Council has the same view in its practical approach as the basis for the conformity of the Assembly's ratification with the general policies of the system, and from the perspective of the Guardian Council, the general policies of the system are considered a form of government rule, and therefore a religious command. In criticizing this view and the manner of the Guardian Council, according to Article 110 of the Constitution, it should be said the only supervisory authority to supervise the proper conduct of the general policies is the Supreme Leader, and the entry of the Guardian Council without explicit permission from the Leader, in fact, the entry to the particular domain of the leadership is contrary to Article 110 of Constitution. Since the Constitution does not entrust any task in this regard to the Guardian Council.

The Islamic Consultative Assembly is required to legislate within the framework of the overall policy of the system since the general policy of the system is one of the examples of "Constitutional limits" set forth in article 71 of the Constitution. in other words, it is from among the legislative restrictions of general policies, that is, the ratification of the Islamic Consultative Assembly should not be in conflict with those policies, and the ratification should be in accordance 
with the General policy of the system. The Guardian Council has, in many respects, reviewed Parliamentary ratification in contradiction with the general policies of the system, which violated Article 110, paragraph 110, and returned them to the Assembly for amendment, which in some way represents the legislative limitation of the Assembly. Because "determining the general policies of the Islamic Republic of Iran" contained in Article 1 of the one and tenth Constitution is one of the duties and powers of the leadership. And the Islamic Consultative Assembly cannot legislate contrary to the general policies of the system.

The Supreme Leader has had a number of general policies on various issues during the formation of the Second, Third and Fourth developmental Plans ... as well as on Economic, Cultural, Energy, Judicial and Infrastructure, Article 44 of the Constitution, and ...identified and issued for the implementation. (Www.majma.ir). It should be noted that at present, based on the Article 110 of Constitution the monitoring of the proper implementation of the overall policy of the system by the authority of the Supreme Leader, who also authorizes them to document the provisions of supervision of the general policy of the system has been delegated to the Expediency Council. Accordingly, the regulations for monitoring the general policies of the system in 2005 were approved by the Supreme Leader. According to Article 1, these Regulations, by virtue of the authority of the Supreme Leader, the supervision of the general policies of the system is carried out by the Expediency Council, and in accordance with Article 2, the laws and regulations of the country shall not be in any way inconsistent with or contrary to the policy. In order to monitor this issue, a commission called the Supervisory Commission will examine the inconsistency or non-compliance of the Islamic Consultative Assembly with the general policy. But, for example, some of the views of the Guardian Council on the overall policy of the system will be listed as follows: Guardian Council in the Opinion No. 82/30/6263 dated 2004/1/4 on the bill on the structure of the comprehensive welfare and social security system approved by the Islamic Consultative Assembly of 2003/11/9 for the sake of being contrary with "welfare and social security policies", which is one of the general policies of the system, considered it as inconsistent with paragraph 1 of Article 110 of the Constitutional Law. In the Opinion number 91/30/46455 dated 2012/4/21 regarding the plan to remove the name of the post bank office from the list of companies subject to the assignment of the law implementing the general policies of Article 44 of the Constitution adopted by the Assembly on 2012/4/15, the Guardian Council considered it to be inconsistent with" General Principles of Principle 44". Also, the Guardian Council, in the opinion No. 94/102/3604 of 2015/9/4, regarding the Prohibition of the Use of Retirees adopted by Assembly on 2015/9/20, considered it as inconsistent with Article 8 of the General Policies of the system of administration, and as a result, it is the opposite of Article 110 of the Constitution. And the other issue is the Opinion No. 25669/30/87 dated 2008/5/16 concerning the draft amendment to the bill on the protection and extension of green spaces in the cities approved by the Revolutionary Council of 1980, adopted by the Islamic Consultative Assembly on 2008/4/15. Because the use of prospected punishments in regard to the proportion of crime to punishment and the imposition of imprisonment in all cases is contrary to general judicial policy and is therefore contrary to article 110, paragraph 1 , of the Constitution.

In the end, it should be noted that, according to the interpretation and the procedure of the Guardian Council, overall policies are part of the Shi'a, and on this basis, the duty of monitoring the compliance of Parliamentary approvals with general policies is the responsibility of the Guardian Council (Aresta, 2001, p. 395).

\section{The Guardian Council}

The Consultative Assembly does not have the right to legislate in the affairs of the Guardian Council. In one case, the Guardian Council, in accordance with the 5091 Opinion of 1982/9/5, concerning the requirement for ministries and state institutions to submit all applicable laws to the Guardian Council approved on 1982/9/5 by the Islamic Consultative Assembly, has been returned to the Assembly because it has assigned the Council of Guardians, to resolve the objection. Because the Consultative Assembly cannot decide for the Guardian Council.

\section{Institutions under the Leadership Undertaking}

"Institutions under the leadership undertaking" are institutions whose names are not mentioned in the Constitution and are not part of the main and fundamental institutions of the country, because the institutions have a certain legal status. This criterion is introduced because ordinary lawmakers are, in most cases, where there is ambiguity about the institution, and of course, the institution has been linked with the supreme leader, has used the term "institutions under the leadership"

1. Determining the duty of the head of the institution that represents the Supreme Leader in the universities without the permission of the Supreme leader is contrary to the provisions of the Shari'a. Also, the membership of two members of the Education and Research Commission by the election of the Islamic Consultative Assembly as a result of intervention by the Assembly is contrary to the principle 57 and 58, and this principle. - Opinion No. 1943/30/81 dated 2002/11/26 concerning the Bill on the Purposes, Duties and Organization of the Ministry of Science, Research and Technology adopted by the Islamic Consultative Assembly on 2001/11/3 Departure of parliamentary Jurisdiction and intervention in the leadership domain).

2. Determination of the criteria for the Special Clerical Court, established by order of the Supreme Leader, by the Consultative Assembly - Opinion No. 1326 dated 2017/12/30 regarding the election plan for the lawyer by the parties 
of the lawsuit approved by the Islamic Consultative Assembly on 10/ 9/1991(Departure of parliamentary Jurisdiction and intervention in the leadership domain)

3. Determination of the disposition for the Supreme Leader - Opinion No. 1485 dated 1991/1/31 regarding the budget bill for the year 1991 of the whole country approved by the Islamic Consultative Assembly on 1991/1/29.

4. Making ambiguity about the powers of the Supreme Leader and limiting his powers by the Islamic Consultative Assembly- Opinion No. 124 dated 1991/5/18 regarding the bill of recruitment regulations of the Islamic Revolutionary Guard Corps approved by the Islamic Consultative Assembly on 1991/5/13.

\section{The Expediency Council}

In the procedure of the Guardian Council, another legislative constraint of the Islamic Consultative Assembly is to legislate on matters of legitimacy in the Expediency Council. In this regard, the commentary Opinion No. 5318 of the Guardian Council dated 1993/10/16 states: "The Consultative Assembly cannot discuss matters that are legislated in the Expediency Council and considered as a system dilemma, to put them again to legislative revision ". According to the interpretation opinion of Guardian Council No. 4575 dated 1993/5/24, the Assembly is responsible for the interpretation of the ratification of the Assembly itself.

And also, the Guardian Council, in safeguarding this jurisdiction, the Expediency Council has repeatedly emphasized its views on the resolutions of the Islamic Consultative Assembly and legislative constraints of the Assembly are such as the following:

1. In the case of a resolution that was previously raised and legislated at the Expediency Council as a system dilemma, the Assembly cannot re-enter and it seems unnecessary and contrary to the Constitution. Opinion No. 1352 dated 1995/12/23 regarding the bill of Islamic Penalties (Compensation and Punishment part), is approved by the Islamic Consultative Assembly on 1995/10/1.

2. The ratification of the Assembly shall not be in conflict with the approbation of the Expediency Council. Opinion No. 75/21/0285 dated 11996/4/16 is concerning with the Bill on Amendments to the Law on the Administration of Free Industrial-Commercial Zones of the Islamic Republic of Iran, approved by the Islamic Consultative Assembly of 1996/4/2.

3. The Assembly cannot establish a law in which the necessary approvals of the Expediency Council are canceled. Opinion No. 82/30/6421 dated 2003/6/1 is on the draft of the guild system of the country approved by the Islamic Consultative Assembly on 2003/12/30.

4. The Assembly shall not legislate the approvals of the Expediency Council. Opinion No. 91 /30/49318 dated 2013/1/30 is concerning the prohibition of employment of more than one occupation approved by the Islamic Consultative Assembly on 2013/1/15.

5. Any change in the approvals of the Expediency Council shall be done by the Expediency Council itself, not by the Islamic Consultative Assembly. Therefore, considering that the law on the implementation of general policies of the article (44) of the Constitution approved by the Expediency Council does not have the right to amend the mentioned law. Opinion No. 92/30/50906 dated 2013/6/3 is regarding with the budget bill of 2013 of the whole country, approved by the Islamic Consultative Assembly of 2013/5/28.

6. The approvals of the Assembly shall not develop the approbations of the Expediency Council. Opinion No. $89 / 30 / 38680$ dated $2010 / 6 / 13$ is on the plan to increase the productivity of agriculture and natural resources approved by the Islamic Consultative Assembly on 2010/5/12.

7. According to the commentary opinion of the Guardian Council, No. 4575 dated 1993/5/3, the interpretation of the approbations of that Assembly is the responsibility of the Assembly itself. Opinion No. 85/30/20216 dated $2007 / 1 / 27$.

8. 85/30/10 is concerning with the drafting procedure of paragraph 3 of part (b) of the single clause bill of the amendment of the addendum note (2) of Article 76 of the amendment of articles (72) and (77) and the addendum of article (76) The Social Security Act passed in 1975 and the addition of two additions to Article 76, passed in 1992, approved by the Islamic Consultative Assembly on 2015/10/19.

It should be noted, however, that the approbation of the Expediency Council, if it relates to a specific year, will be devoted to the same year, and will not be applicable to subsequent years. Opinion No. 84/30/12858dated 2005/7/6 is regarding with the bill on the use of foreign financial resources approved by the 2005/6/26 Islamic Consultative Assembly.

As noted above, in general, the Parliamentary resolution should not be in conflict with the approbation of the Expediency Council. And the Consultative Assembly cannot cancel the binding approvals of the Expediency Council. And any change, semantic disambiguation, amendment, interpretation of the resolutions of the Council is the responsibility of the Council itself and the Assembly has no right to interfere. And on the other hand, the Assembly 
cannot refer its ratification to the Expediency Council on the basis of the interpretation of the Guardian Council from article 112 of the Constitution until it is clarified.

\section{The Supreme National Security Council}

Another legislative constraint of the Islamic Consultative Assembly is that in the procedure Guardian Council in regard to the legislative authorities in special cases, of the Supreme Council of National Security has the right to restrict or impose restrictions on the jurisdiction of the council. For example, the Guardian Council in the Opinion No. 83/30/7466 dated 2004/5/23 regarding the bill of the Fourth Economic, Social and Cultural Development Plan of the Islamic Republic of Iran approved by the Islamic Consultative Assembly of 2004/5/2, in which the Islamic Consultative Assembly rejected one of the delegated functions of the Supreme National Security Council to the Ministry of Information. And, the Opinion No. 93/102/303 of 2015/2/21 is concerning with the bill on the determination of protection-security prohibited zone of the dwellings and installations of the country approved by the Islamic Consultative Assembly 2014/4/6. The Guardian Council disagreed by the delegation of one of the duties of the Supreme National Security Council to the headquarters of the armed forces. And it also, according to the Opinion number 91/30/49318 of 2013/1/30 on the prohibition of employment for more than one occupation approved by Assembly in 2013/2/15, which led to the observance of the authority of the Supreme National Security Council, was disagreed. Regarding the above-mentioned opinions, it was found that the Guardian Council has been in opposition to the legislature of the Islamic Consultative Assembly in the jurisdiction of the Supreme National Assembly.

\section{The Supreme Council of the Cultural Revolution}

The Guardian Council does not have the jurisdiction to legislate with regard to the powers and responsibilities associated with the Supreme Council of the Cultural Revolution, and this was approved by the Guardian Council Opinion No. $89 / 30 / 38832$ dated $2010 / 7 / 3$ on the proposal to support the establishment and strengthening of non-governmental institutions' institutes and higher education. 2011/1/20 of the Islamic Consultative Assembly has been emphasized. In other words, the Assembly cannot legislate that embodies to enter into the jurisdiction of the Supreme Council of the Cultural Revolution. And in this respect, there is a legislative limit.

\section{THE PROVISION OF THE LAW BY THE EXECUTIVE BRANCH OR PARLIAMENTARY COMMISSIONS}

In the Islamic Republic of Iran, the Islamic Consultative Assembly is a unique legal authority. According to the Constitution, members of Assembly cannot, in principle, who have the task of legislating except in the case referred to in Article 59, which refers to referring directly to the votes of the people for the exercise of the legislative authority by the approval of two-thirds of the total sum of parliamentarians, to delegate the responsibility of legislation to another person or authority. In this regard, Article 85 stipulates: "The position stands in adventitious and cannot be delegated to another person, the Assembly cannot delegate legislative authority to a person or group ..." Of course, this prohibition, in accordance with Article 85 has two exceptions which include: "The delegation of legislative power to the interior commissions of the Assembly in two cases and the delegation of legislative power to the government in one case (Mehrpour, 1993, p. 209). Of course, as mentioned at the initiation of Article 85, the Assembly may, in cases of necessity, give up the power to ratify certain rules. The Guardian Council has, so far, put forward some examples in its opinions. This council does not have a permanent law passed by the Islamic Consultative Assembly and a legal vacancy is considered as one of the factors justifying the necessity of delegating the approval of trial rules to the commissions. As opinion No. 89/30/41230 dated 2011/1/18. Also, according to the Guardian Council's view, the approval of the approbations of the commissions should be made explicit because, if it is not trial and interim, the delegation of the mandate of the Islamic Consultative Assembly is unconstitutional, the Guardian Council considers this point as important and, and in cases where the trial rules of the commissions approved by the courts have not been clarified, it has declared the Assembly's bill contrary to Article 85 of the Constitution. For example, Article 75 of the Bill on Amendments to the Law on the Organization, Duties and Elections of the Islamic Councils of the City and Village.

The provisions of Article 85 of the Constitution, in some ways, are under the question, including the fact that it is not clear that the Constitution of the state is of nature in the field of legislation or in the sphere of implementation? Moreover, this principle is foreseen on the one hand by the chairman of the Assembly, while on the other side, the Guardian Council's consideration is that this parallel job will be a dilemma. When the Guardian Council is supposed to examine a bill, it may have a legislative nature and therefore it is considered as law and, given the general spirit of the ruling the Constitutional law, it should be monitored by the Guardian Council. Now, if this is the case, the supervision of the Islamic Consultative Assembly will be considered doubtfully.

\section{THE LOCAL LEGISLATION BY LOCAL ISLAMIC COUNCILS}

the views of the Guardian Council under Article 100 of the Constitution, as it has been emphasized in Opinion No. $82 / 30 / 3500$ dated 2003/7/9, councils have the task of supervisory which is the subject matter of the article. Therefore, the powers and duties of the councils cannot be exceeded by the 100th principle. (Opinion No. 85/3/3/20377 of 2007/2/7) Therefore, as stated in Opinion. No. 5511 dated 1982/9/23, in addition to the oversight of the supervisory powers and functions of the Islamic councils the following is as such: Permission to maintain security in the area of council activity, permission to conduct charitable activities and establish a charitable fund, permission to the elimination of differences 
between the people and reconciliation of two parties, permission to the dissolution of any council, the election and dismissal of the village elder, the formation of religious classes outside the functions and powers of the councils and as well as the establishment of taxes by the councils (Opinion No. 81/30/2190 dated 2003/1/11). In general, according to the views of the Guardian Council, the development of the duties and authorities of the councils exceeds of what is mentioned in the hundredth principle, is contrary to the Constitution and in other words, the Islamic Consultative Assembly cannot go legislating beyond the provisions of the above-mentioned principle.

Of course, by looking at the seventh principle of the Constitution, and with the attention to the seventh chapter of this law, as well as the study of the views of the Guardian Council in this regard, one can conclude that the legal status of councils in the political system of the country is not clear. Because, contrary to that the seventh principle of the Constitution, the councils are part of the decision-making body of the country. According to the views of the Guardian Council based on the principles of 100 - 107 of the Constitution, the councils are not considered as a decision-making body in the political system of the country. On the other hand, cannot, in contravention of the laws of the country, take a decision in the local area and, meanwhile, in accordance with the principle of Article 71 Constitution, Assembly can legislate even in local matters within the jurisdiction of the mentioned Councils.

\section{CONCLUSION}

In the Constitution of the Islamic Republic of Iran, the principle is based on the general jurisdiction of the legislature of the Islamic Consultative Assembly, but because of the nature of the Islamic system and the specific requirements and different objectives pursued, other authorities, like other political systems of the world, are somehow allowed to pass the law in the matter and special cases have been identified, in other words, legislation has been delegated to other institutions in certain specific fields. In the Constitution of the Republic of Iran, in addition to the Islamic Consultative Assembly, there are eight other authorities that are prospected, such as the enactment of law through a referendum (Article 59), the approbation by the jurisprudents of the first Council of Guardians (Article 108), the adoption of regulations by the leadership of the experts (Article 108), Approval of regulations by the Expediency Council (Article 112), ratification of regulations by the Supreme National Security Council (Article 176), Revision of the Constitution by the Revision Council (Article 177); Provision of local regulations by Islamic councils (Articles 7, 12, 100 to 102); The ratification of law by the executive branch or the Parliamentary commissions (Article 85) and the Guardian Council as the Constitutional guard in several opinions many of which this authority has been safeguarded. In other words, the Islamic Consultative Assembly has a legislative limit in these cases. Of course, it should be noted that the authorities of the legislation system in Iran's legal system are more than those mentioned, the above are of the Constitutional origin. Otherwise, there are authorities such as the Supreme Council of the Cultural Revolution, the Supreme Council of Cyberspace and other councils as regulatory authorities. In short, in the procedure of the Guardian Council regarding the acceptance of numerous legislatures, the Guardian Council, in its Opinion No. 1646/2236/1 dated 1994/3/9, responded to the question of the head of the Expediency Council regarding "whether the Islamic Consultative Assembly and other centers which in some way have the right to determine the rules and regulations, can refuse, violate or cancel the resolutions of the Assembly?" Such an interpretation has been made: "None of the legislation authorities has the right to reject, revoke, and to terminate the resolution of the Assembly of The Expediency of the system, but if the resolution of the Expediency Council was about the conflict of ideas between the Guardian Council and the Islamic Consultative Assembly, the Assembly would, after a long period of time, that the change of justification is vindicated, has the right to draft and approve the conflicting law. In cases where the issue has been sent to the Assembly as a matter of dilemma by the Supreme Leader, in the event of the inquest of the Supreme Leader and the lack of opposition of the Supreme Leader, the issue may be raised in the Islamic Consultative Assembly." (Guardian Council Research Center, 2010, p. 178). As can be witnessed, in this interpretation, by using the term "legislative authorities", firstly, the existence of legislative institutions other than the Islamic Consultative Assembly has been recognized. And secondly, despite the fact that the core duty of these authorities is not legislative, they are authorized to legislate on specific issues and areas. Thirdly, the Islamic Consultative Assembly does not have the right to legislate and enter into matters approbated by them and what is considered as under the jurisdiction of these authorities, and, in other words, has a legislative limit.

\section{REFERENCES}

1. Alem, A. (2003). The Foundations of Political Science. Tehran: the publication of Ney. (p. 237).

2. Ansari, M. (2006). The Position of General Policies in the Legislative System in Iran. Proceedings of the Conference of the 100th Anniversary of Legislation.

3. Aresta, M. (2001). Investigation in the Legal Status of General Policy. Strategic Quarterly. Tehran.

4. Arjmand, A. (2001). The Overall Policy of the System in the Light of the Rule of Law and Republican Rule. Strategic Quarterly, 26. (No date). Familiarity with the Supreme Council of the Cultural Revolution. Tehran: Secretariat of the Supreme Council of Cultural Revolution, General Directorate of Public Relations.

5. Fallah Zadeh, A. (2018). Separation of Legislation and Execution. Guardian Council Institute.

6. Ghazi, A. (1988). Political Parties and Influencing Groups. Tehran: Tehran University.

7. Ghazi Shariat Panahi, A. (1994). The Requirements of Fundamental Rights (pp. 27-33).

8. Gholkhani, A. J. (2015). Legislative Compilation of the Islamic Republic in the Good Governance Scale. Sirjan: Printing and Publishing Organization of Islamic Azad University, Scientific Publishing Center. 
9. Gholam Hossein, A., \& Nouraie, M. (2015). Thoughts of Public Rights. The Unity or Multiplicity of Legislators in the System of the Islamic Republic of Iran and its Effect on the Administrative System, (p. 7-22.)

10. Habibnejad, S. A. (1999). Tasks and Powers of the Assembly of Experts. Compilation of legitimacy. Andishe Javan Center.

11. Hamidian, H. (2010). Legislative Monitoring in Iran and the United States. Dadgostar Publishing

12. Hossein Ali, A. (2016). Pathology of the Legislative System in the Islamic Republic of Iran with a Comparative Study of French law. Publishing Al Mizan.

13. Hossein Ali, A. (2016). The Legislative System in the Islamic Republic of Iran with a Comparative Study of French law; Pathology (p. 159). Publishing Al Mizan.

14. Hosseini, S. E. (2012). Limitations of the Islamic Consultative Assembly in Legislation; Compilation of the Islamic Government (al-Mjeld 4).

15. Javan Araste, H. (2013). Compilation of the Basics of Islamic State. Boostan Institute.

16. Khomeini, R. (1999). Sahifah Imam. Tehran: The Institute for the Arrangements and Publishing of Imam's Works.

17. Katouzian, N. (2006). Volume II Philosophy of Law (p. 70). Joint Stock Company.

18. Lak zaie, S. (2003). Typological Typical Writing of the Separation of Triple Forces in the Providence of the Faqih. Strategic Research Center (Strategy) No. 26.

19. Lufan Boomer, F. (2006). Great Currents in the History of Western Thought. Tehran: Majlis Research Center. (pp. 540-544)

20. Najafi, M. \& Mohseni, F. (2009). The Basic Tights of the Islamic Republic of Iran (p. 25). International Alhadi Publications.

21. Najafi, M., \& Mohseni, F. (2009). The Basic Rights of the Islamic Republic of Iran. Alhadi International Publishing.

22. Neumann, F., (1994). A. and. Law on Freedom, Power and Law. Tehran: Kharazmi Publications.

23. Nouraei, M. (2013). The Number of Legislative Bodies in the Islamic Republic of Iran. Tehran: Office of Law and Legislation Studies.

24. Madani, S. J. (1995). Compilation of Comparative Fundamental Rights. Library of Ganje Danesh.

25. Malmiry, A. (2006). Rule of Law, Concepts, Foundations, Concepts. Tehran: House of Research Center.

26. Mehrpour, H. (1993). New Perspectives on Legal Issues. Tehran: Etelaat.

27. Montesquieu, Sh. (1983). Spirit of the Law. In the publication of Amir Kabir.

28. Musa Zadeh, I. (2008). A Survey on the Concept of the Nature and Legal Status of the Overall Policy of the System. Compilation of jurisprudence and law (p. 174).

29. Musa Zadeh, I. (2010). Compilation of the Basic Proceedings in the Islamic Republic of Iran. Guardian Council Research Center.

30. Rasekh, M. (2011). Supervision and Balance in the System of Fundamental Rights. Drack Publishing.

31. Rustami, et all., \& Gotbi, M., (2014). An Analysis of the Concept of Institutions under the Leadership of Iran's Legislative System. Journal of Legal Studies (pp. 69-90).

32. Tabatabaei Motamani, M., (2001). Basic Rights. Tehran: Mizan Publishing.

33. Zanjani, Amid. et all., (2010). Supervision of the Administration of Justice and Administration. Tehran: Tehran University Press. (1106-1107). Volume II Compilation of the Detailed Report of the Constitution al Review Council of the Islamic Republic of Iran. Digital References: The Guardian Council's Constitution al Law File System. (No date). Recover from http://www.shora-rc.ir/Portal/home/?news/12410/237109/15467/ \%D8\%A7\%D8\%B5\%D9\%84-7-\%D9\%82\%D8\%A7 \% D9\% 86\% D9\% 88\% D9\% 86\% D8\% A7\% D8\% B3\% $\mathrm{D} 8 \% \mathrm{~A} 7 \% \mathrm{D} 8 \% \mathrm{~B} 3 \% \mathrm{D} 9 \%$ 8A

34. Approvals of the Expediency Council. (no date). (Expediency Council); digital source http://www.majma.ir

35. Kasteyeva, M. (2018). Belgium priority as a partner for the Republic of Kazakhstan. Opción, 34(85-2), 752772. 